Prepared for the U.S. Department of Energy

under Contract DE-AC05-76RL01830

\title{
Quality Assurance Review of ISOTOPE and ORIGEN Decay Masses for PWR Fuel (51 GWd/MTU)
}

JA Gastelum

March 2011

Pacific Northwest

NATIONAL LABORATORY

Proudly Operated by Battelle Since 1965 


\title{
DISCLAIMER
}

This report was prepared as an account of work sponsored by an agency of the United States Government. Neither the United States Government nor any agency thereof, nor Battelle Memorial Institute, nor any of their employees, makes any warranty, express or implied, or assumes any legal liability or responsibility for the accuracy, completeness, or usefulness of any information, apparatus, product, or process disclosed, or represents that its use would not infringe privately owned rights. Reference herein to any specific commercial product, process, or service by trade name, trademark, manufacturer, or otherwise does not necessarily constitute or imply its endorsement, recommendation, or favoring by the United States Government or any agency thereof, or Battelle Memorial Institute. The views and opinions of authors expressed herein do not necessarily state or reflect those of the United States Government or any agency thereof.

\author{
PACIFIC NORTHWEST NATIONAL LABORATORY \\ operated by \\ BATTELLE \\ for the \\ UNITED STATES DEPARTMENT OF ENERGY \\ under Contract DE-AC05-76RL01830
}

Printed in the United States of America

Available to DOE and DOE contractors from the

Office of Scientific and Technical Information,

P.O. Box 62, Oak Ridge, TN 37831-0062;

ph: (865) 576-8401

fax: $(865) 576-5728$

email: reports@adonis.osti.gov

\footnotetext{
Available to the public from the National Technical Information Service, U.S. Department of Commerce, 5285 Port Royal Rd., Springfield, VA 22161 ph: (800) 553-6847 fax: $(703) 605-6900$

email: orders@ntis.fedworld.gov

online ordering: http://www.ntis.gov/ordering.htm
}

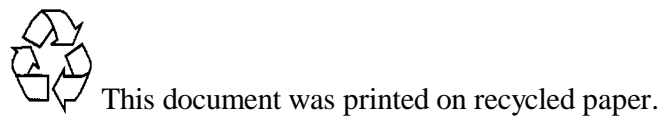




\section{Quality Assurance Review of ISOTOPE and ORIGEN Decay Masses for PWR Fuel (51 GWd/MTU)}

JA Gastelum

March 2011

Prepared for the U.S. Department of Energy under Contract DE-AC05-76RL01830

Pacific Northwest National Laboratory

Richland, Washington 99352 


\section{Table of Contents}

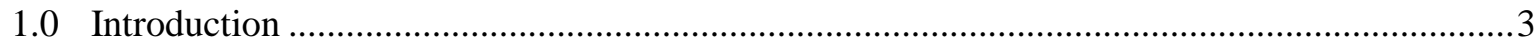

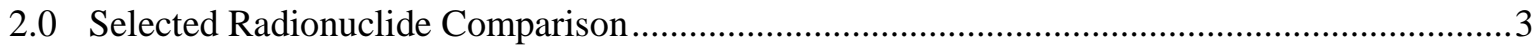

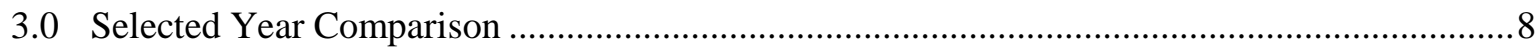

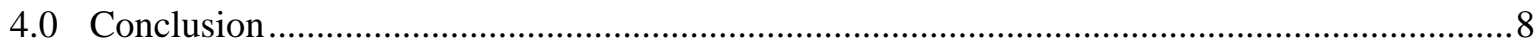

\section{Table of Tables}

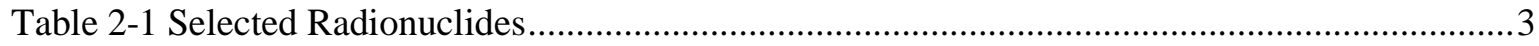

Table 3-1 Results of Selected Year Comparison .......................................................................8

\section{Table of Figures}

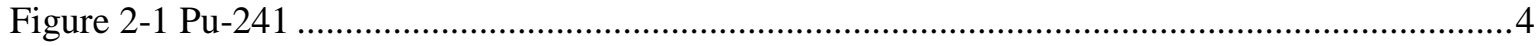

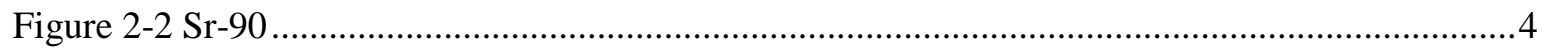

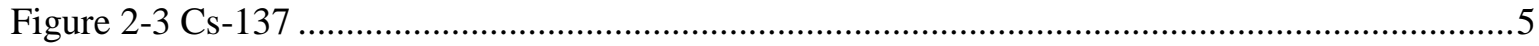

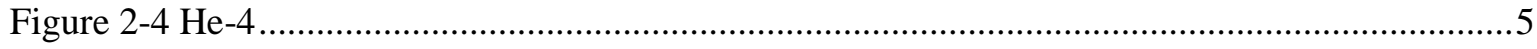

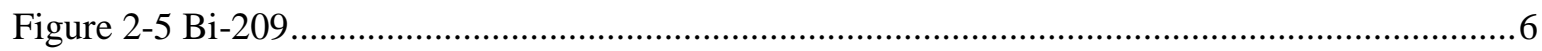

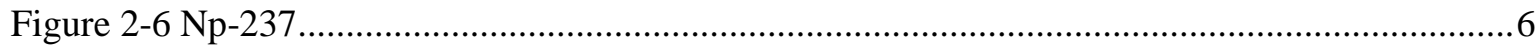

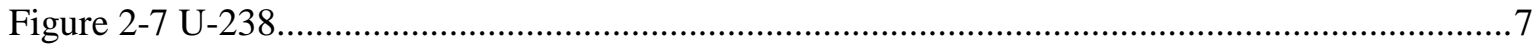


PNNL-20283

\subsection{Introduction}

ISOTOPE and ORIGEN are two tools that compute the mass of radionuclides as they decay over time. In an effort to provide decay heat figures for selected used nuclear fuels, the UFD campaign identified ISOTOPE as the preferred tool to compute radionuclide masses. ISOTOPE was selected over ORIGEN because of its relative ease to integrate with current tools used to calculate waste stream volumes associated with selected fuels and fuel cycles.

This memorandum documents the comparison of decay mass calculations for PWR fuel with burnup of $51 \mathrm{GWd}$ /MTU in ISOTOPE with analogous calculations in ORIGEN. Two comparisons were made: a "horizontal cut" comparing the masses of selected radionuclides over time; and a "vertical cut" comparing the masses of radionuclides common to both tools at selected years.

\subsection{Selected Radionuclide Comparison}

This section compares masses, over time, computed using ISOTOPE and ORIGEN for selected radionuclides. Table 2-1 lists the radionuclides selected for comparison, the principle decay mode, and the sum of the absolute difference in mass over the range of 1.00E-01 to 2.00E+06 years after discharge. $\mathrm{Pu}-241$, Cs-137, Sr-90, and He-4 were included for comparison per the direction of the project manager. $\mathrm{Bi}-209, \mathrm{~Np}-237$, and U-238 were included because they were responsible for the three largest sums of absolute difference in mass between ISOTOPE and ORIGEN.

Figures 2-1 through 2-7 plot the mass over time from ISOTOPE and ORIGEN for the selected radionuclides. Masses were plotted for years common to both data sets over the range of $1.00 \mathrm{E}-01$ to $2.00 \mathrm{E}+06$ years after discharge.

Visual inspection of the figures indicates that for years less than $7.00 \mathrm{E}+03$, the masses are nearly identical. For Np-237 the difference only first exceeds one gram in year 2.00E+06, the last year in which results are computed in ORIGEN. For Bi-209 the difference only first exceeds one gram in year $2.00 \mathrm{E}+05$. For $\mathrm{U}-238$, the first larger than one gram difference in mass occurs substantially earlier, in year 7.00E+03. However, even in year $2.00 \mathrm{E}+06$, the difference in calculated mass for U-238 was only 885 grams. This represents less than one tenth of a percent difference in calculated mass between ISOTOPE and ORIGEN.

Table 2-1 Selected Radionuclides

\begin{tabular}{|c|c|r|}
\hline Radionuclide & Decay Type & $\begin{array}{c}\text { Sum of Absolute } \\
\text { Difference in Mass (g) }\end{array}$ \\
\hline Pu-241 & Beta & 5.64 \\
\hline Cs-137 & Beta & 7.17 \\
\hline Sr-90 & Beta & 0.99 \\
\hline He-4 & Stable & 108.41 \\
\hline Bi-209 & Stable & 466.26 \\
\hline Np-237 & Alpha & 489.55 \\
\hline U-238 & Alpha & $3,360.36$ \\
\hline
\end{tabular}




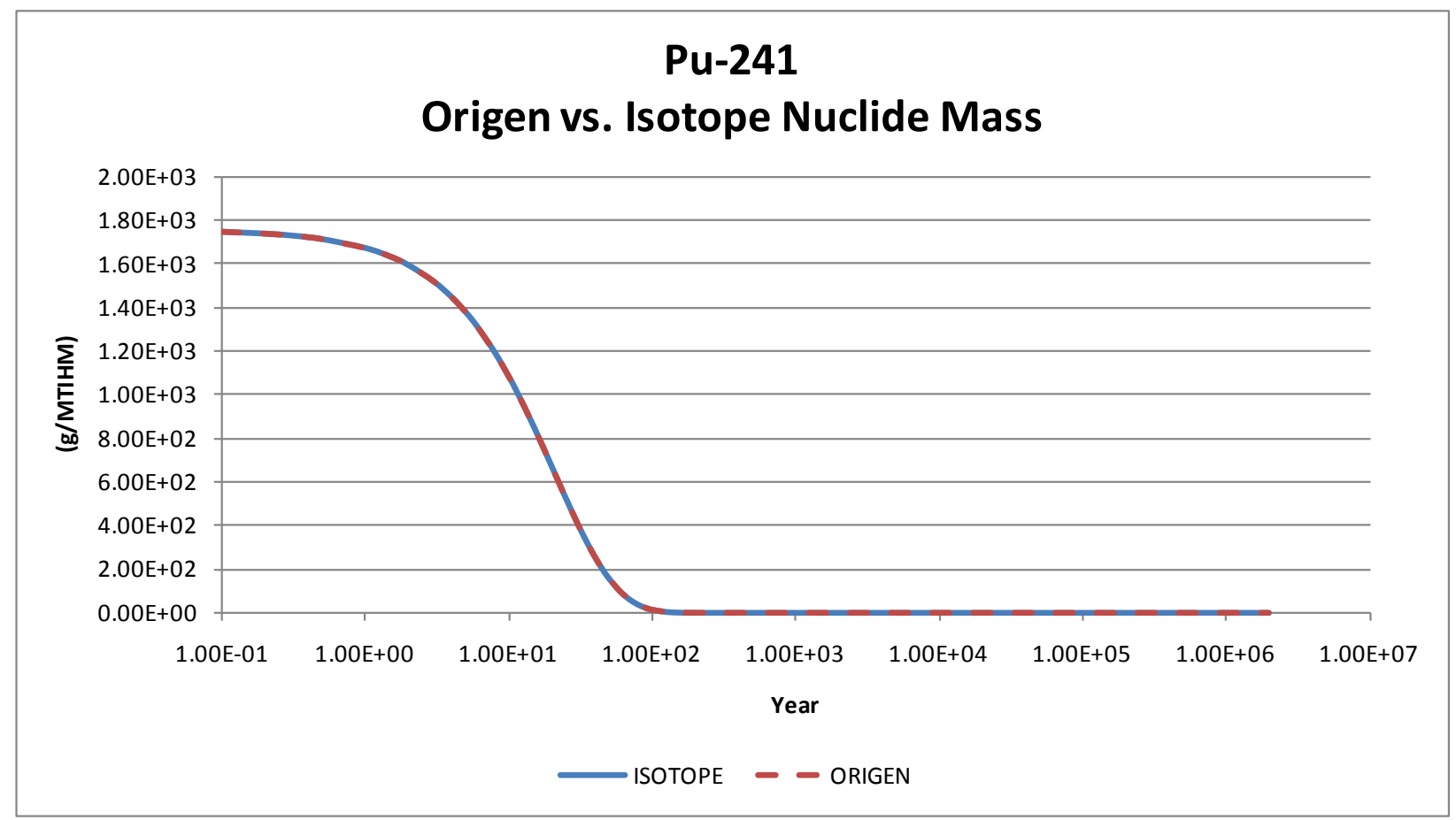

Figure 2-1 Pu-241

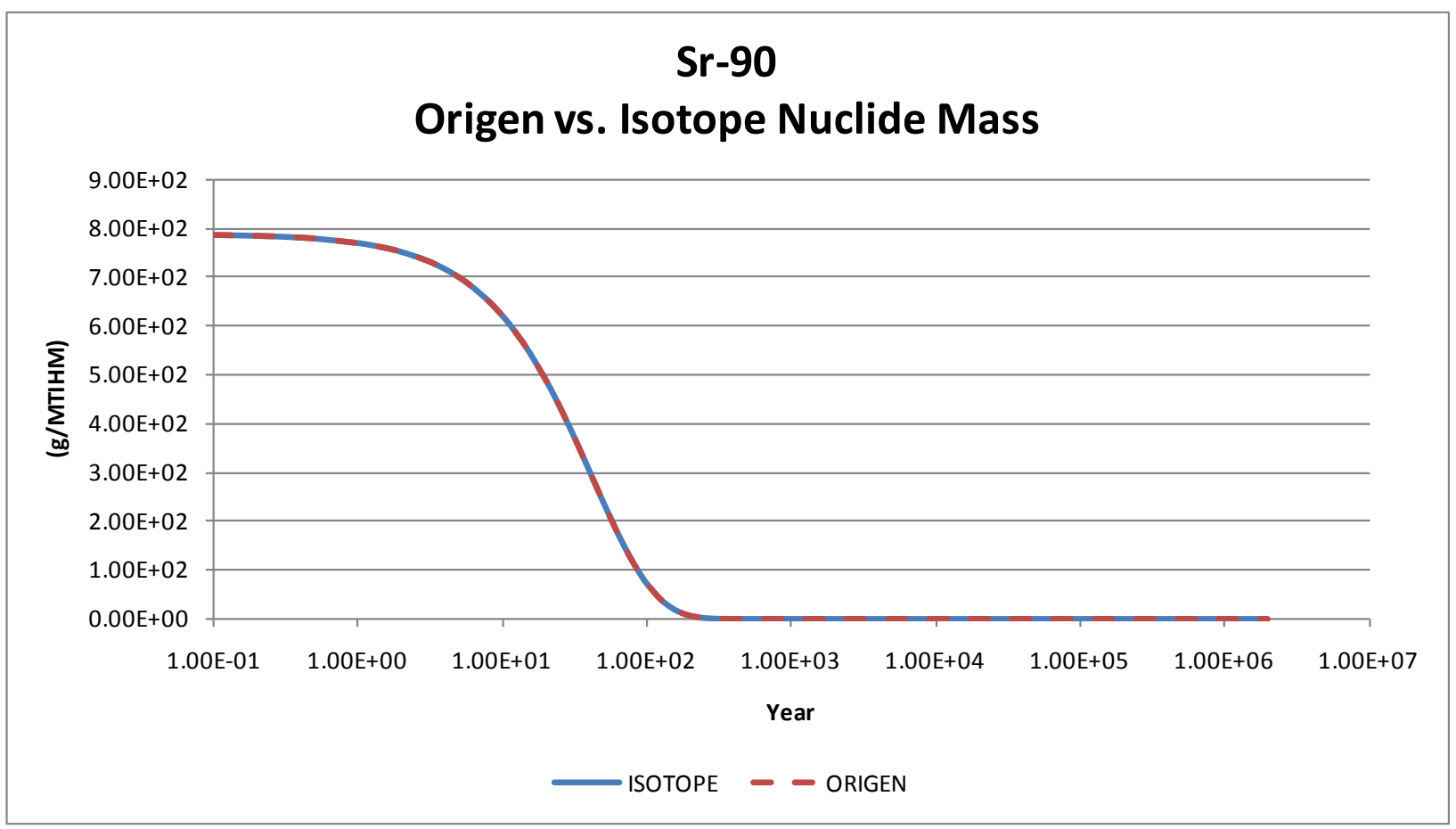

Figure 2-2 Sr-90 


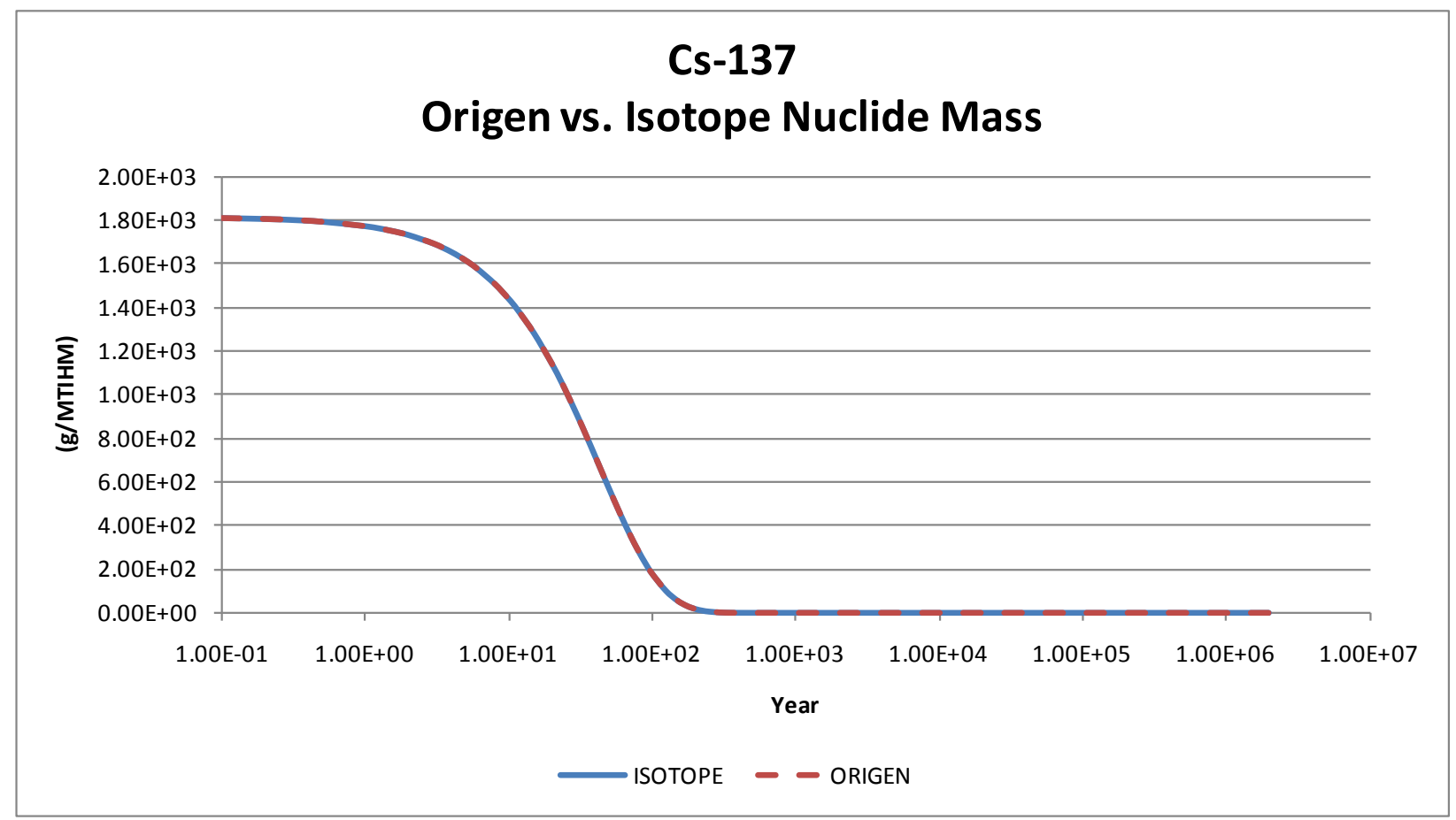

Figure 2-3 Cs-137

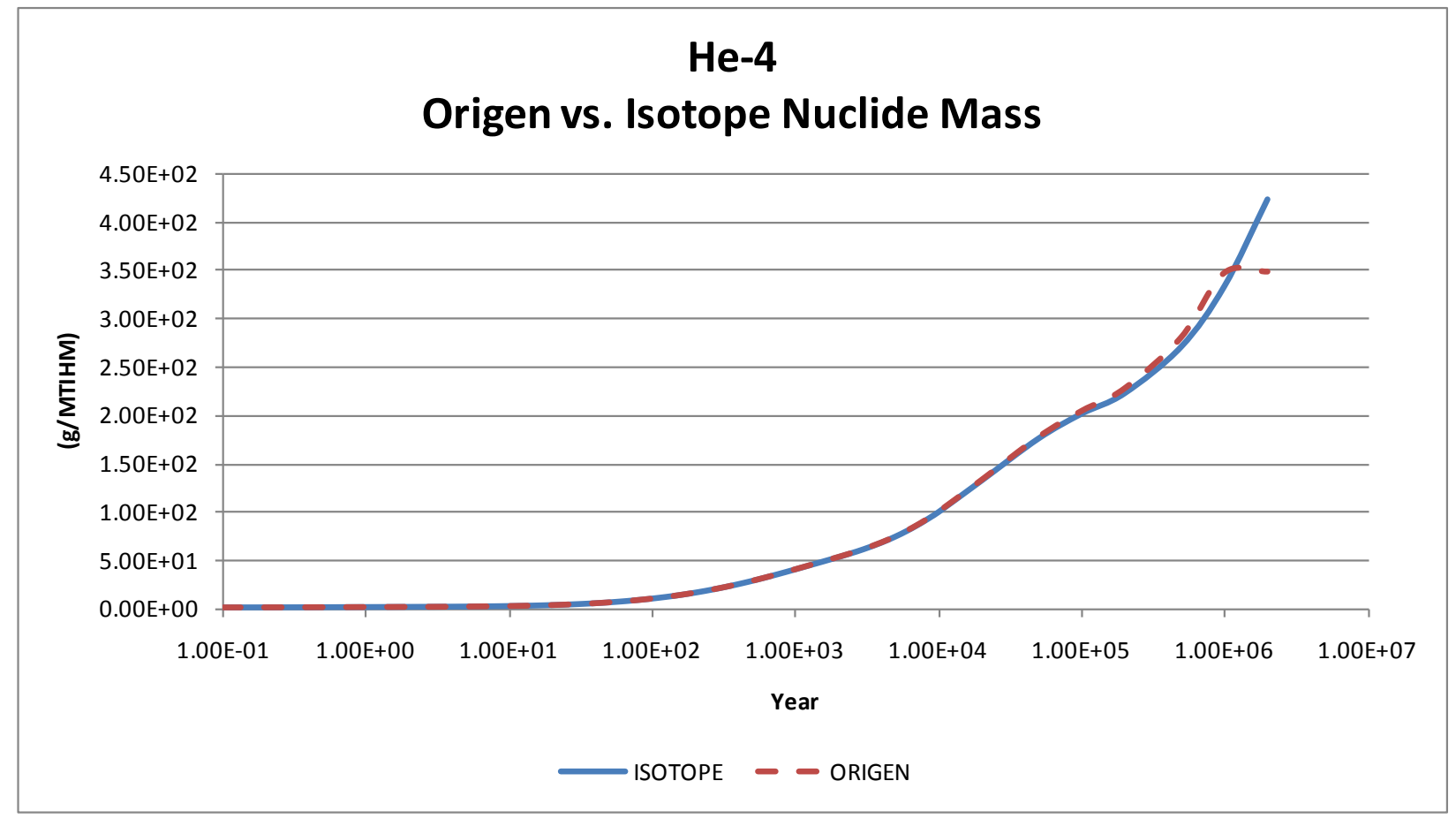

Figure 2-4 He-4 


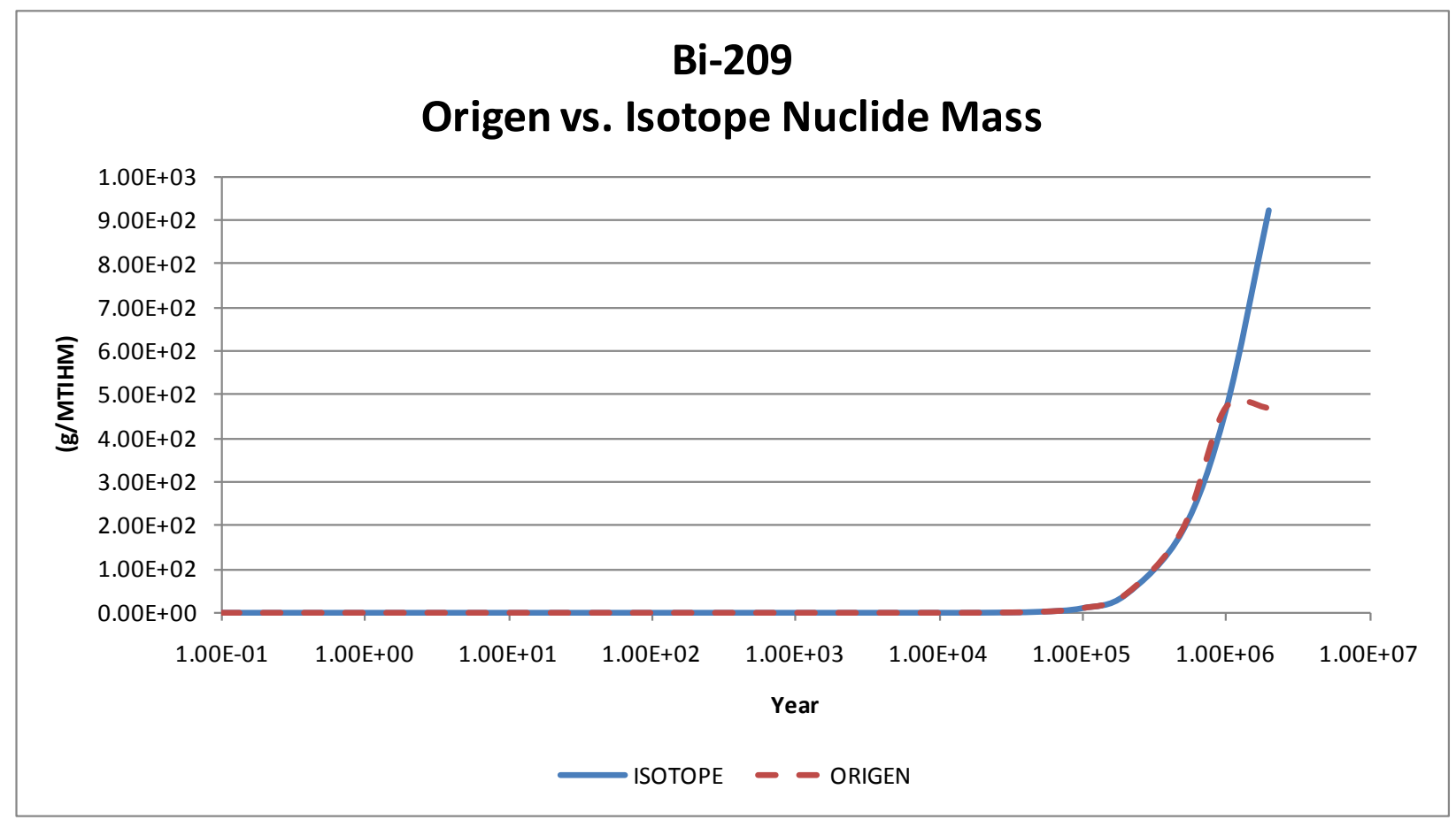

Figure 2-5 Bi-209

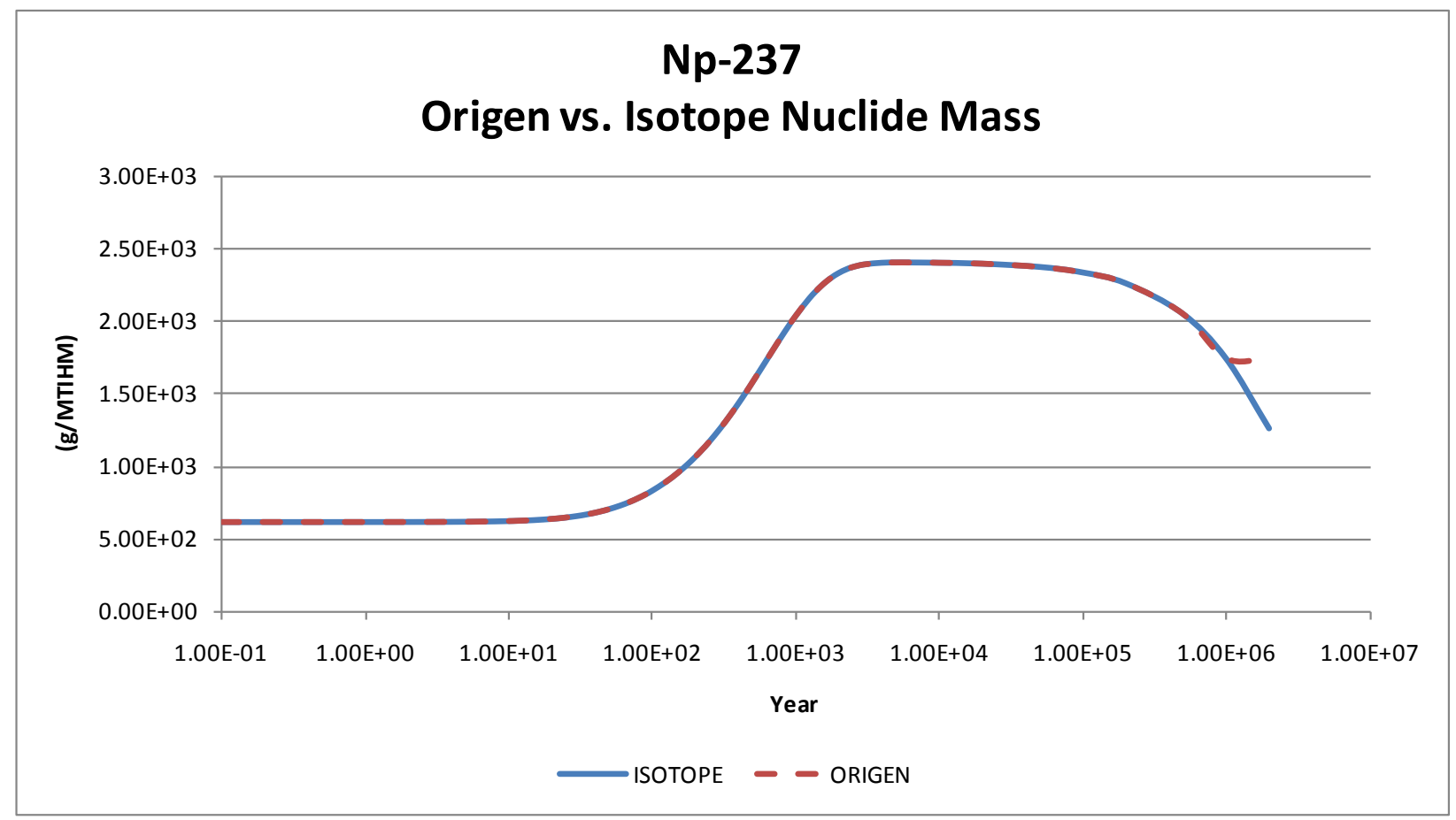

Figure 2-6 Np-237 


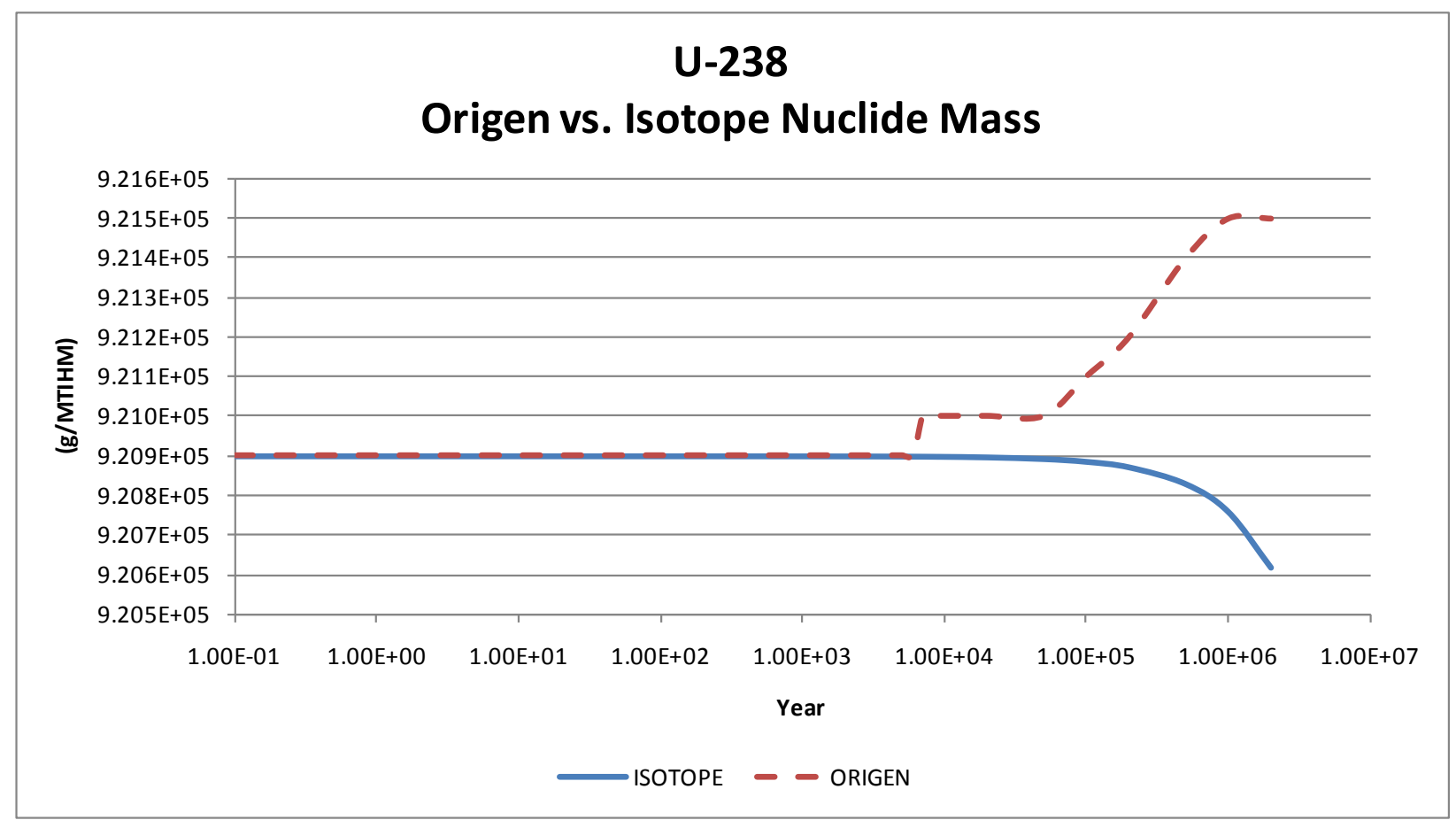

Figure 2-7 U-238 


\subsection{Selected Year Comparison}

This section compares the difference in decay mass for each of the 1,005 radionuclides common to both ISOTOPE and ORIGEN for nine common years spanning the decay calculations. The sum of the absolute difference in decay mass, over all common radionuclides, is presented in column two of Table 3-1. This figure is represented as a percent of the total ORIGEN mass in column three. Table 3-1 also displays the radionuclide with the largest difference in mass for each time period in column four, and the magnitude of the difference in column five.

Results indicate that while the sum of differences generally increases with time, even at year $1.00 \mathrm{E}+06$ the sum of differences is less than a tenth of a percent of the total ORIGEN mass for all radionuclides.

Table 3-1 Results of Selected Year Comparison

\begin{tabular}{|r|r|r|r|r|}
\hline Year & $\begin{array}{c}\text { Sum of Difference in } \\
\text { Decay Mass }\end{array}$ & $\begin{array}{c}\text { Percent of Total } \\
\text { ORIGEN Mass }\end{array}$ & $\begin{array}{c}\text { Radionuclide with } \\
\text { Max Difference }\end{array}$ & $\begin{array}{c}\text { Max } \\
\text { Difference }\end{array}$ \\
\hline $0.00 \mathrm{E}+00$ & 0.00 & $0.00000 \%$ & & \\
\hline $1.00 \mathrm{E}-01$ & 7.01 & $0.00070 \%$ & Pr141 & 0.82 \\
\hline $1.00 \mathrm{E}+00$ & 7.33 & $0.00073 \%$ & $\operatorname{Pr} 141$ & 0.93 \\
\hline $1.00 \mathrm{E}+01$ & 7.40 & $0.00074 \%$ & $\operatorname{Pr} 141$ & 0.91 \\
\hline $1.00 \mathrm{E}+02$ & 6.95 & $0.00070 \%$ & Pr141 & 0.91 \\
\hline $1.00 \mathrm{E}+03$ & 6.41 & $0.00064 \%$ & U238 & 101.42 \\
\hline $1.00 \mathrm{E}+04$ & 107.88 & $0.01080 \%$ & U238 & 214.15 \\
\hline $1.00 \mathrm{E}+05$ & 226.61 & $0.02267 \%$ & $\mathrm{U} 238$ & 742.12 \\
\hline $1.00 \mathrm{E}+06$ & 773.44 & $0.07735 \%$ & & \\
\hline
\end{tabular}

\subsection{Conclusion}

This analysis indicates that decay mass calculations for PWR fuel with burnup of $51 \mathrm{GWd} / \mathrm{MTU}$ using ISOTOPE yield essentially the same results as those calculated using ORIGEN for the first thousand years after discharge from the reactor. While the results for the two methodologies begin to diverge after this time for some radionuclides, the difference in mass across all radionuclides is still less than a tenth of a percent of the ORIGEN mass even at one million years. 